\section{養殖イシダイにみられたイクチオ ホヌス症について}

\author{
片山美和*1 ・畑井喜司雄*1 $・$ 寉田三朗*1 \\ 後藤政則 $* 2$ \\ ( ${ }^{* 1}$ 日本獸医畜産大学, *2佐賀県水産試験場)
}

1987 年 5 月中旬より 6 月上旬にかけて, 佐賀県内の A 荃魚場で飼育中のイシダイに憼死が発生した。その原 因を主に病理組織学的に究明した結果, 擎死原因は Ichthyophonus hoferi に起因するすのであると判断された。 我が国に拈ける本症の発生はこれ穼でブリ1, =ジマ $ス^{2)}$ ，クロダイ ${ }^{1)}$ 小よびア ユ $^{3)}$ などの養殖魚に確認され ているが，盖殖イシダイでの記載はない。

本報では湌殖イシダイで初めて確認されたイクチオホ 又ス症についてその発生経過怙よび病理組織学的所見に ついて述べる。

\section{発生経過}

イシダイは海面小割生筫 $(5 \times 5 \times 5 \mathrm{~m})$ に当初約 1000 尾が収容され，慨料として生サバを冬期は 1 日に $5 \mathrm{~kg}$ が，また擎死発生時には $10 \mathrm{~kg}$ が給䭒され，飼育されて いた。羅病魚は急速に整死することはなく網隅に奇り， 緩慢遊泳後擎死する傾向を示した。本症は水温の上昇に 伴い自然終息したが，発生よりその終息までの擎死魚数 は約 50 尾であった。

嶅死魚は外観的に異常がみられず，剖検所見では鰓弁 の点状発赤执よび白点, 脾藏の肥大抽よび微小白点, 腎 臓の腫張, 腹腔内脂肪に黄脂塊の沈着を呈した。病魚の 腎蔵から $0.5 \%$ または $2 \% \mathrm{NaCl}$ 加 BHI, BTBT およ び CTA 培地を用いて細菌の分離培養を試みたが, 細菌 の発育はみられなかった。また腎臓からの塗抹標本（メ チレンブルーの単染色) 中にる細菌が確認されなかった ことから, 憼死原因は細菌感染に起因するるのではない と判断された。

\section{病理組織学的所見}

瀕死魚の 1 尾を $10 \%$ 中性ホルマリン水で固定後, 常 法に従ってパラフィン切片とし， HE， PAS，ギムザお よびアザンマロリー染色を施して観察に供した。

球形の寄生体は観察したほぼ全ての蔵器（腎臓, 脾 缄, 肝臓, 膵臓, 心藏, 鰓, 消化管, 䇗肉) にみられた が，それらの感染病巣には繁殖性炎および肉芽腫性炎が 諗められ，さらに寄生体からの発芽像むみられたことか ら,これらはIchthyophonus hoferi の多核球状体之判断 された。
腎臓における病変は最も頭著であり, 種々の発育段階 にある多核球状体がみられ（図 1)，それらはマクロファ 一シ，類上皮細胞などに囲まれ肉芽腫を形成していた。 さらに，しぱしば肉芽腫内に巨細胞（異物型）が観察さ れた（図 2)。また肉芽腫は時に，多世代性肉芽腫を形成 乙(図 3), その内部が乾酪壊死を呈している像户，尿 細管が变性萎縮し, 間質が壊死している部位も認められ た。多核球状体は脾䁍, 肝臓（図 4) 飞子多数認められ， それらの周囲には脾藏では肉芽腫の形成, 肝臓ではマク ロフフージ主体の単核性細胞が出現し (図 5), 肝細胞索 の萎縮, 部位によっては巣状壊死も認められた。心臟に は心室筋層に少数の多核球状体が出現していた。鰓では 鰓薄板の毛細血管内に小型の球状体が寄生し (図 6), そ の部位の上皮は肥厚していた。胃では粘膜上皮に多数の 多核球状体がみられ，上皮の崩壊または消失部位には侵 入門戸の形跡が認められた。また胃底部にも肉芽腫の形 成がみられたが，その粘膜下織には乾酪壊死像もみられ た。腸管拉よび幽門垂の上皮にも壊死がみられ，多核球 状体とそれに反応してマクロファージ，巨細胞および線 維芽細胞などが出現して括り, 粘膜下織には顕著な好中 球,リンパ球の浸潤が認められた。膵蘎は脂肪化が進行 しており，そこには多核球状体がみられた。体僋筇組織 にも多核球状体が観察されたが，その周囲の組織反応性 は乏しかった。球状体は皮膚拉よび卵巣には認められな かった。

多核球状体は種々の発育段階を呈し, しかもそれらを 包囲している炎症細胞の反応などからその感染はかなり 慢性的な状態にあると判断された。

TIMUR ら") は本症に感染した天為カレイの同一病変 部に 2 種類の巨細胞, すなわち Langhans 型と巽物型を 観察しているが, ニホンウナギ11, ニジマス稚魚 ${ }^{5)}$ およ び成魚帛ささらには今回のイシダイでは異物型巨細胞のみ が認められ若干椂相を異にしたが，これは魚種による相 違ではないかと推察された。

な拉，今回の本症発生はイシダイに生サバのみが給餌 されていたことからそれに感染源が存在していた可能性 が疑わ机る。

\section{文献}

1) 簡 肇衡・宮崎照雄・寉田三朗 (1979): 三重大水 産研報, 第 6 号, 129-146. 2) 小野威・兼子樹広・ 粟倉輝彦・青海昭紀 (1966): 水産䍀化場 研 究 報告, 第 21 号, 43-53. 3) MrYAZAKI, T. and Y. Jo (1985): Fish Pathology, 20, 45-48. 4) Timur, G. and M. Timur (1984): J. Fish Diseases, 7, 513-514. 5) 宮 崎照雄 - 䆶田三朗 (1977a): 三重大水産研報, 第 4 号, 45-56. 6) 宮崎照雄・洼田三朗 (1977b)：三重大水産 研報，第 4 号， 57-65.

(昭和 63 年 6 月 1 日受付) 


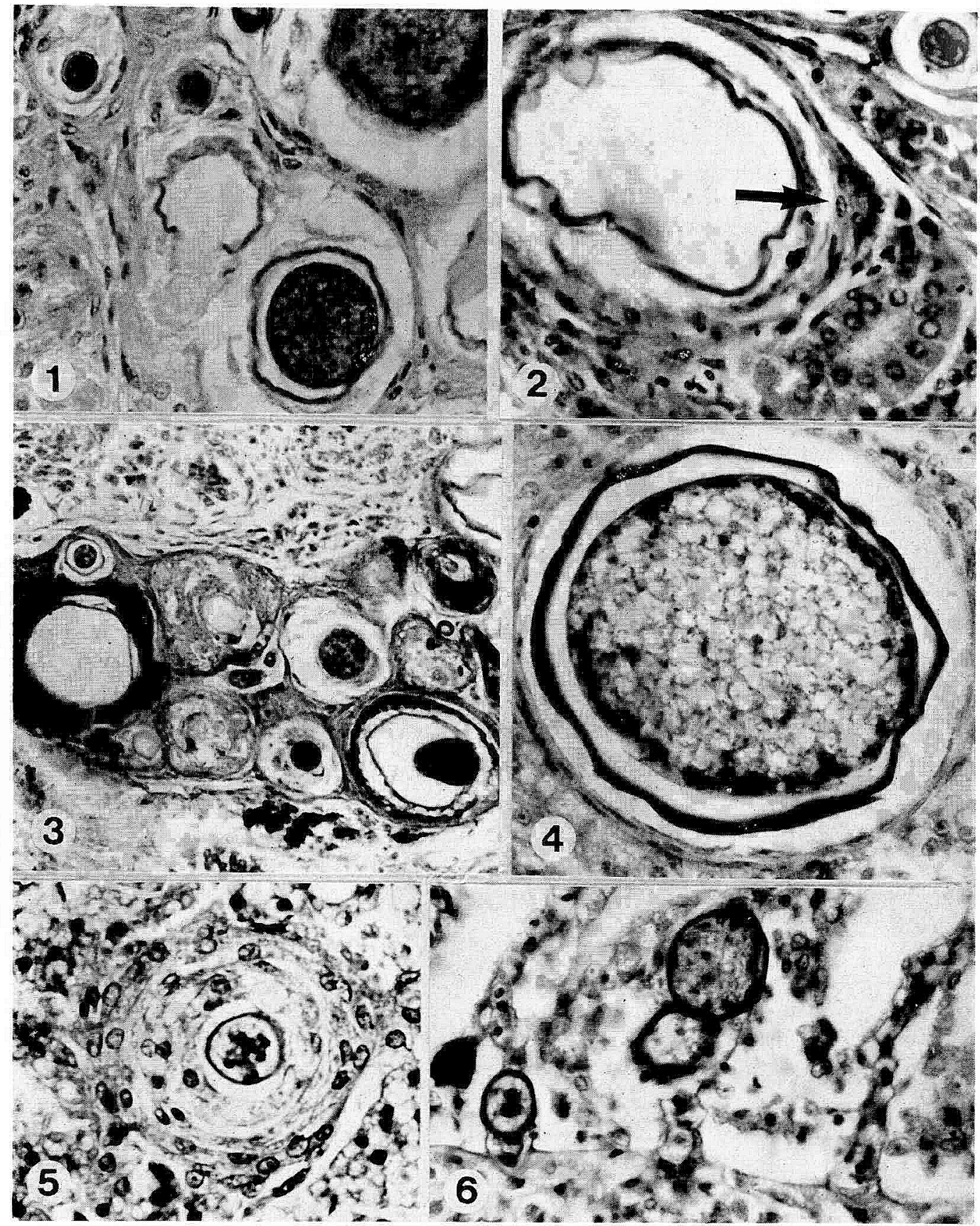

図 1 腎茼に見られた多核球状体，HE 染色 $(\times 400)$

図 2 中空の多核球状体の周囲に見られた異物型巨細胞 (矢印)。腎臓。HE 染色 $(\times 400)$

図 3 堅腷に見られた多世代性肉芽腫。アザンマロリー染色 $(\times 200)$

図 4 㟁散に見られた多核球状体. PAS 染色 $(\times 400)$

図 5 多核球状体の周囲に形成さ九た肉芽腫. HE 染色 $(\times 200)$

図 6 鰓薄板の毛細血管内に寄生する多核球状体. PAS 染色 $(\times 400)$ 